\title{
Four mediation models of teacher expectancy effects on students' outcomes in mathematics and literacy
}

\author{
Sławomir Trusz ${ }^{1}$
}

Received: 6 December 2016/Accepted: 14 November 2017/Published online: 19 December 2017

(c) The Author(s) 2017. This article is an open access publication

\begin{abstract}
The study tested 4 direct and 28 indirect teacher expectancy effects on students' results in the mathematics and literacy sections of the matriculation test, and their final marks in the 12th-grade mathematics and literacy class. The following were considered as mediators: student self-esteem, their self-expectancy, and time spent learning mathematics and literacy. The study involved 1374 first year college students. Conducted path analyses revealed: (1) the total teacher expectancy effects was the strongest for final marks in mathematics, followed by test results in mathematics, test results in literacy, and final marks in literacy; (2) the direct effect was stronger than the total indirect teacher expectancy effects in the case of mathematics, while for literacy outcomes, the order of the effects was reversed; (3) the direct teacher expectancy effects were positive; the indirect effects reversed after including student self-esteem/student self-expectancy into relations between teachers' expectancy and mathematics and literacy outcomes; (4) teachers' expectancy was mediated most strongly by student self-esteem, time spent learning, and student self-expectancy, or by student self-expectancy and time spent learning, respectively for mathematics and literacy outcomes; (5) the impact of teachers' expectancy was stronger than student self-expectancy for mathematics, but was the same or weaker for literacy outcomes, respectively. The obtained results were discussed in the light of the theory and results of studies concerning teacher expectancy effects.
\end{abstract}

Keywords Teacher expectancy effects · Mediation · Self-esteem · Self-expectancy · Effort · Mathematics and literacy outcomes

Sławomir Trusz

trusz@up.krakow.pl

1 Institute of Educational Sciences, Pedagogical University in Kraków, 4 Ingardena St., 30-060 Kraków, Poland 


\section{Introduction}

Interpersonal expectancy effects in education have been studied intensively for several decades (Dusek 1985; Blanck 1993; Jussim 2012; Trusz and Bạbel 2016). The impact of teacher expectancy on the development of the cognitive competencies of students was experimentally tested for the first time by Rosenthal and Jacobson (1968). Induction of inaccurate teacher expectancy at the beginning of a school year in relation to an alleged intellectual blooming of random students in grades 1-6 after 8 months of studying resulted in positive changes in the students' cognitive skills. For example, in grades 1 and 2, the improvement in IQ test results of experimental students, as compared to control ones, was higher by 27.40 and 16.50 points on average. However, no such effects occurred in other grades.

Ambiguous results of the Pygmalion experiment are a source of an ongoing dispute in the academic world (Jussim and Stevens 2016; Willard and Madon 2016). The study is criticised for numerous methodological errors and expressing in the report opinions that are consistent with popular beliefs concerning teachers' lack of competencies (Snow 1995; Spitz 1999; Wineburg 1987). Finally, in a series of meta-analyses summarising the results of subsequent studies verifying the Pygmalion hypothesis, it was demonstrated that expectancy effects are a real phenomenon affecting educational outcomes of a large group of students (Harris and Rosenthal 1985; Rosenthal 1997; Rosenthal and Rubin 1978). In one of the last meta-analyses, based on the results of 674 studies, Hattie (2008) established that the size of teacher expectancy effect is $d=0.43$. This means that approximately $65-70 \%$ of low/high-expectancy students show lower/higher than expected outcomes after a certain time, taking into consideration their actual level of skills.

The effects observed in the Pygmalion experiment can be explained within the framework of an educational self-fulfilling prophecy mechanism (Blanck 1993; Dusek 1985; Bạbel and Trusz 2016). This mechanism was formally defined for the first time by Merton (1948), who assumed that it could occur when three conditions were fulfilled: (1) the observer forms inaccurate expectancies concerning the object; (2) the observer passes the inaccurate expectancies to the object; and (3) the object confirms the original inaccurate expectancies of the observer by acting in accordance with them.

\subsection{The teacher expectancy induction process}

Teacher expectancy concerns the qualities of students that are important from the point of view of the teacher's social and professional role, e.g., intelligence, motivation to study, children's diligence, etc. These expectancies are characterised by varying degrees of accuracy (Brophy 1985; Jussim 2012; Olson et al. 1996).

Target-based expectancies (Jones 1990), i.e., predictions based on the observations of children's behaviours in various contexts, over a longer period of time, tend to be accurate; therefore, although they are a good predictor of future outcomes (Jussim 2012; Jussim and Stevens 2016), by definition (Merton 1948), they cannot be a source of the self-fulfilling prophecy phenomenon. In contrast, category-based 
expectancies (Jones 1990), i.e., predictions derived from stereotypes, are characterised by low accuracy, as a result of which in favourable circumstances, e.g., teachers' lack of access to in-depth information on an interaction partner, a specific set of teacher and student personality traits (Babad 2009; Neuberg 2016; Swann and Ely 1984), lead to self-fulfilling prophecies (Babad et al. 1982; Willard and Madon 2016).

Some researchers (Jussim 2012; Jussim and Harber 2005; Jussim et al. 1996) claim that even stereotypes are a source of accurate teacher expectancy, as they reflect actual differences concerning properties of various groups. However, others (c.f. de Boer et al. 2010; Peterson et al. 2016; Speybroeck et al. 2012; van den Bergh et al. 2010) argue that teacher expectancy is a significant source of the self-fulfilling prophecy phenomenon because of their initial inaccuracy. Speybroeck et al. (2012), for instance, demonstrated that information on the socio-economic status of students was a source of varied teacher expectancy even after controlling for prior children's mathematics and language outcomes, which in turn were significantly associated with their current mathematics $(\beta=.14)$ and language $(\beta=.17)$ outcomes.

In another large-scale study, de Boer et al. (2010) quantified that teacher expectations were only accurate for $33 \%$ of students, whereas for others, teacher expectancy was not accurate, i.e., they were too high or too low for approximately 34 and 33\% of them, respectively. Moreover, Jussim et al. (1996) points out that the effects of incorrect teacher expectancy could be particularly strong among minority students and victims of multiple stigmas, e.g., children with special educational needs from families of relatively low socio-economical status. Teachers form expectancies concerning students based on different information, e.g., their outcomes, effort put into learning, sex, physical attractiveness, etc. (Dusek and Joseph 1983; Good and Brophy 2008; Rubie-Davies 2015). The first two sources lead to the formation of accurate, target-based expectancies, while the last two lead to the formation of less accurate, category-based, stereotype-tinged expectancies.

\subsection{The teacher expectancy communication process}

When triggered, expectancies are communicated through a range of verbal and nonverbal behaviours (Harris 1993). In a series of 31 meta-analyses, Harris and Rosenthal (1985) distinguished over a dozen behaviours used by teachers to communicate expectancies concerning students' outcomes, e.g., eye contact, praise, encouraging activity, etc.

These behaviours can be connected with four mediation factors of the model of communicating interpersonal expectancies developed by Rosenthal (1974) and his colleagues (Harris and Rosenthal 1985, 1986), i.e., climate, feedback, input, and output. In Harris and Rosenthal's (1985) meta-analyses, indicated factors yielded an effect size of $\mathrm{r}=.27, .10, .29$, and .19 , respectively. Finally, taking into consideration the relatively small effect of the teacher feedback, Rosenthal (1989) transformed the four factors theory into an affect-effort model of expectancy communication highlighting the importance of emotional and learning support provided to students by teachers (see also Babad 2009). 


\subsection{The teacher expectancy confirmation process}

The confirmation of expectancy in the classroom can take place in a real or perceptual dimension (Miller and Turnbull 1986; Jussim 1989, 2012; Snyder and Klein 2005). In the former case, high versus low-expectancy students begin to present objectively higher/lower outcomes in consequence of receiving preferential/ non-preferential treatment (Jussim et al. 1996; Snyder and Stukas 1999). In the latter case, due to cognitive bias, the teacher gives a bias evaluation of students' outcomes, i.e., in accordance with the formerly assumed hypotheses (Jussim et al. 1996; Olson et al. 1996).

Expectancy can also be falsified in the course of social interactions when students present outcomes that are consistent with their actual level of abilities or personality structure/temperament and not inaccurate teacher expectancy. However, falsification may induce various defence mechanisms, e.g., biased attributions reducing an unpleasant state of cognitive dissonance (Darley and Fazio 1980; Levesque and Lowe 1992; Olson et al. 1996), which leads to a phenomenon referred to as an expectancy perceptual confirmation.

\subsection{Factors affecting the strength/direction of teacher expectancy effects}

The process of inducing, communicating, and confirming teacher expectancy can be modified by a number of personal and situational intervening factors (Rubie-Davies 2016). These factors determine the strength and/or direction of the influence of information on students, on the expectancies formed by teachers, e.g., a low level of cognitive complexity (cf. Brophy 1985; Cooper and Hazelrigg 1988; Harris 1989; Jussim 1986, 2012; Li 2016), teacher expectancy concerning their behaviours, e.g., attributions of student behaviours (cf. Cooper 1985; Darley and Fazio 1980; Good and Brophy 2008; Jussim 1986, 2012; Levesque and Lowe 1992; Li 2016) and teacher behaviours in response to student behaviour (e.g., interaction aims, cf. Brophy 1985; Darley and Fazio 1980; Hilton and Darley 1991; Jussim 1986, 2012; Li 2016; Neuberg 2016). Thus, these factors also determine the strength and/or direction of the effects of interpersonal expectancy in the classroom.

The author will now proceed in discussing three intervening factors (psychological mediators, cf. Jussim 1986) in detail: (1) student self-esteem; (2) their selfexpectancy; and (3) effort put into learning.

\subsubsection{Student self-esteem}

Consistent communication of teacher expectancy may be an important source of differences in student self-esteem/self-schemata (Eccles and Wigfield 1985; Jussim 1986; Rubie-Davies 2006; Weinstein 2002). In unfavourable educational circumstances student self-esteem may deteriorate, and analogically it may improve in more favourable conditions.

Furthermore, self-esteem is closely related to students' outcomes. In a metaanalysis covering 324 studies, Hattie (2008) calculated that student self-esteem/selfschemata for their outcomes yielded an effect size of $d=.43$. This means that 
approximately $65-70 \%$ of students with high/low self-esteem/self-schema will experience improvement or deterioration in their educational outcomes over time.

High self-esteem/self-schemata affect the motivation to study, especially in the face of emerging difficulties, which in turn increases the level of students' outcomes. In contrast, students with negative self-esteem give up their activities when faced with failure, which leads to a decrease in their outcomes (Dweck and Master 2009).

It follows that student self-esteem/self-schemata in specific circumstances act as a psychological regulator of a relationship between teacher expectancy and students' outcomes (Baumaister et al. 2003; Valentine et al. 2004). Self-esteem can also be a mediator in the relationship between teacher expectancy and student selfexpectancy. In this situation, consistent communication of teacher expectancy leads to important changes in self-esteem and, subsequently, self-expectancy of students (Hansford and Hattie 1982), and ultimately to an increase/decrease in their outcomes. Alternatively, self-esteem can be a mediator in the relationship between teacher expectancy and student self-expectancy, which in turn may affect the effort put into learning (Dweck and Master 2009; Eccles and Wigfield 1985; Madon et al. 1997) and, ultimately, educational outcomes.

\subsubsection{Student self-expectancy}

A series of studies conducted since the mid-1970s (Brattesani et al. 1984; Kuklinski and Weinstein 2001; Weinstein et al. 1982; Weinstein and Middlestadt 1979) showed that the differential treatment of students in the classroom provided indicators based on which they formed self-expectancy, correlating with teacher expectancy.

For instance, Brattesani et al. (1984) established that teacher expectancy accounted for approximately $4 \%$ of the variance of student self-expectancy concerning their reading skills, with the relationship between the indicated variables considerably stronger in classes with a higher PDT (perceived differential treatment) index. In a later study, Kuklinski and Weinstein (2001) evaluated the relationship between teacher expectancy and student self-expectancy concerning reading in grades 1,3 , and 5 . The relationship was significant only in grade 5, characterised by a high PDT index. Furthermore, student self-expectancy was significantly correlated with their reading outcomes in grades 3 and 5. It can be concluded that in certain circumstances (high PDT index), with reference to specific groups of students, differential teacher expectancy affects children's educational outcomes through their self-expectancy.

In addition, it also cannot be ruled out that self-expectancy may be a mediator in the relationship between student self-esteem formed on the basis of teacher expectancy, effort put into learning and, finally, educational outcomes (Eccles and Wigfield 1985). Positive self-expectancy formed on the basis of an optimistic selfimage may significantly affect the motivation expressed in the amount of time dedicated to learning and raising competencies despite difficulties (Dweck and Master 2009). 


\subsubsection{Student effort put into learning}

Teacher expectancy may affect student motivation and hence also the effort they put into learning. Cooper (1985) showed that high-expectancy students are more often awarded by teachers for the effort put into learning, which reinforces their conviction that the time dedicated to learning is a more important source of academic success than circumstances which are beyond their control (Dweck and Master 2009). In contrast, low-expectancy students receive a greater amount of noncontingent feedback, forming a belief that their academic outcomes are independent of their efforts. Accordingly, they may dedicate less time to learning and get more easily discouraged in the face of difficulties (Good and Brophy 2008; Sędek and Kofta 1990).

Furthermore, the effort put into learning has an important and direct influence on students' academic outcomes. In a meta-analysis including 100 studies, Hattie (2008) calculated that the average effect size of learning time on academic success is $\mathrm{d}=.38$. This means that there will be a deterioration or improvement in performance over the course of an academic year in approximately $60-65 \%$ students who dedicate an above or below average amount of time to learning.

As teacher expectancy affects the effort put into learning by students, and the effort affects their academic success, it can be assumed that the indicated factor acts as an important mediator in the relation: teacher expectancy-students' outcomes. Consistent communication of differentiated teacher expectancy may lead students to form a conviction about the existence versus non-existence of the covariance of effort and outcomes, which in turn leads to changes in learning time and, after a while, to a distinct improvement or deterioration in the presented results (Dweck and Master 2009; Hattie 2008; Jussim 1986).

\subsection{Objectives}

This study attempts to estimate the extent to which teachers' expectancy directly affects students' outcomes at high school, i.e., the results of the mathematics and literacy sections of the matriculation test, and their final marks in the 12th-grade mathematics and literacy class, and the extent to which this influence is mediated by: student self-esteem, their self-expectancy on outcomes, and the declared time spent learning mathematics and literacy.

The study quantified 4 direct and 28 indirect teacher expectancy effects on the results of the mathematics and literacy sections of the matriculation test, and the final marks in mathematics and literacy. The direct and indirect paths, and their relevant numbers are presented in Table 1.

Accordingly, the study realised four objectives to establish: (1) the domain of students' outcomes in which the direct effect of teachers' expectancy is weaker or stronger than the indirect effect; (2) the size of the total teacher expectancy effects on students' outcomes; (3) the order of importance of mediators in the relationship between teachers' expectancy and students' outcomes; and (4) whether student selfexpectancy affects their outcomes to the same degree and in the same direction as teachers' expectancy. 
Table 1 Direct and indirect effects of teachers' expectancy on students' outcomes in mathematics and literacy

\begin{tabular}{|c|c|c|}
\hline $\begin{array}{l}\text { Mediation } \\
\text { model }\end{array}$ & $\begin{array}{l}\text { Number of } \\
\text { path }\end{array}$ & Components \\
\hline \multirow[t]{8}{*}{1} & ind1 & $\begin{array}{l}\text { Teachers' expectancy } \rightarrow \text { student self-esteem } \rightarrow \text { results of the mathematics } \\
\text { section of the matriculation test }\end{array}$ \\
\hline & ind 2 & $\begin{array}{l}\text { Teachers' expectancy } \rightarrow \text { student self-esteem } \rightarrow \text { student self- } \\
\text { expectancy } \rightarrow \text { results of the mathematics section of the matriculation test }\end{array}$ \\
\hline & ind 3 & $\begin{array}{l}\text { Teachers' expectancy } \rightarrow \text { student self-esteem } \rightarrow \text { time spent learning } \\
\text { mathematics } \rightarrow \text { results of the mathematics section of the matriculation } \\
\text { test }\end{array}$ \\
\hline & ind 4 & $\begin{array}{l}\text { Teachers' expectancy } \rightarrow \text { student self-esteem } \rightarrow \text { student self- } \\
\text { expectancy } \rightarrow \text { time spent learning mathematics } \rightarrow \text { results of the } \\
\text { mathematics section of the matriculation test }\end{array}$ \\
\hline & ind5 & $\begin{array}{l}\text { Teachers' expectancy } \rightarrow \text { student self-expectancy } \rightarrow \text { results of the } \\
\text { mathematics section of the matriculation test }\end{array}$ \\
\hline & ind6 & $\begin{array}{l}\text { Teachers' expectancy } \rightarrow \text { student self-expectancy } \rightarrow \text { time spent learning } \\
\text { mathematics } \rightarrow \text { results of the mathematics section of the matriculation } \\
\text { test }\end{array}$ \\
\hline & ind 7 & $\begin{array}{l}\text { Teachers' expectancy } \rightarrow \text { time spent learning mathematics } \rightarrow \text { results of the } \\
\text { mathematics section of the matriculation test }\end{array}$ \\
\hline & $\operatorname{dir} 1$ & $\begin{array}{l}\text { Teachers' expectancy } \rightarrow \text { results of the mathematics section of the } \\
\text { matriculation test }\end{array}$ \\
\hline \multirow[t]{8}{*}{2} & ind8 & $\begin{array}{l}\text { Teachers' expectancy } \rightarrow \text { student self-esteem } \rightarrow \text { results of the literacy } \\
\text { section of the matriculation test }\end{array}$ \\
\hline & ind 9 & $\begin{array}{l}\text { Teachers' expectancy } \rightarrow \text { student self-esteem } \rightarrow \text { student self- } \\
\text { expectancy } \rightarrow \text { results of the literacy section of the matriculation test }\end{array}$ \\
\hline & ind 10 & $\begin{array}{l}\text { Teachers' expectancy } \rightarrow \text { student self-esteem } \rightarrow \text { time spent learning } \\
\text { literacy } \rightarrow \text { results of the literacy section of the matriculation test }\end{array}$ \\
\hline & ind 11 & $\begin{array}{l}\text { Teachers' expectancy } \rightarrow \text { student self-esteem } \rightarrow \text { student self- } \\
\text { expectancy } \rightarrow \text { time spent learning literacy } \rightarrow \text { results of the literacy } \\
\text { section of the matriculation test }\end{array}$ \\
\hline & ind 12 & $\begin{array}{l}\text { Teachers' expectancy } \rightarrow \text { student self-expectancy } \rightarrow \text { results of the literacy } \\
\text { section of the matriculation test }\end{array}$ \\
\hline & ind 13 & $\begin{array}{l}\text { Teachers' expectancy } \rightarrow \text { student self-expectancy } \rightarrow \text { time spent learning } \\
\text { literacy } \rightarrow \text { results of the literacy section of the matriculation test }\end{array}$ \\
\hline & ind 14 & $\begin{array}{l}\text { Teachers' expectancy } \rightarrow \text { time spent learning literacy } \rightarrow \text { results of the } \\
\text { literacy section of the matriculation test }\end{array}$ \\
\hline & $\operatorname{dir} 2$ & $\begin{array}{l}\text { Teachers' expectancy } \rightarrow \text { results of the literacy section of the matriculation } \\
\text { test }\end{array}$ \\
\hline \multirow[t]{4}{*}{3} & ind 15 & $\begin{array}{l}\text { Teachers' expectancy } \rightarrow \text { student self-esteem } \rightarrow \text { the final marks in the } 12 \text { th- } \\
\text { grade mathematics class }\end{array}$ \\
\hline & ind 16 & $\begin{array}{l}\text { Teachers' expectancy } \rightarrow \text { student self-esteem } \rightarrow \text { student self- } \\
\text { expectancy } \rightarrow \text { the final marks in the } 12 \text { th-grade mathematics class }\end{array}$ \\
\hline & ind 17 & $\begin{array}{l}\text { Teachers' expectancy } \rightarrow \text { student self-esteem } \rightarrow \text { time spent learning } \\
\text { mathematics } \rightarrow \text { the final marks in the } 12 \text { th-grade mathematics class }\end{array}$ \\
\hline & ind 18 & $\begin{array}{l}\text { Teachers' expectancy } \rightarrow \text { student self-esteem } \rightarrow \text { student self- } \\
\text { expectancy } \rightarrow \text { time spent learning mathematics } \rightarrow \text { the final marks in the } \\
\text { 12th-grade mathematics class }\end{array}$ \\
\hline
\end{tabular}


Table 1 continued

\begin{tabular}{|c|c|c|}
\hline $\begin{array}{l}\text { Mediation } \\
\text { model }\end{array}$ & $\begin{array}{l}\text { Number of } \\
\text { path }\end{array}$ & Components \\
\hline & ind19 & $\begin{array}{l}\text { Teachers' expectancy } \rightarrow \text { student self-expectancy } \rightarrow \text { the final marks in the } \\
\text { 12th-grade mathematics class }\end{array}$ \\
\hline & ind 20 & $\begin{array}{l}\text { Teachers' expectancy } \rightarrow \text { student self-expectancy } \rightarrow \text { time spent learning } \\
\text { mathematics } \rightarrow \text { the final marks in the } 12 \text { th-grade mathematics class }\end{array}$ \\
\hline & ind 21 & $\begin{array}{l}\text { Teachers' expectancy } \rightarrow \text { time spent learning mathematics } \rightarrow \text { the final } \\
\text { marks in the } 12 \text { th-grade mathematics class }\end{array}$ \\
\hline & $\operatorname{dir} 3$ & $\begin{array}{l}\text { Teachers' expectancy } \rightarrow \text { the final marks in the } 12 \text { th-grade mathematics } \\
\text { class }\end{array}$ \\
\hline \multirow[t]{8}{*}{4} & ind 22 & $\begin{array}{l}\text { Teachers' expectancy } \rightarrow \text { student self-esteem } \rightarrow \text { the final marks in the } 12 \text { th- } \\
\text { grade literacy class }\end{array}$ \\
\hline & ind 23 & $\begin{array}{l}\text { Teachers' expectancy } \rightarrow \text { student self-esteem } \rightarrow \text { student self- } \\
\text { expectancy } \rightarrow \text { the final marks in the } 12 \text { th-grade literacy class }\end{array}$ \\
\hline & ind 24 & $\begin{array}{l}\text { Teachers' expectancy } \rightarrow \text { student self-esteem } \rightarrow \text { time spent learning } \\
\text { literacy } \rightarrow \text { the final marks in the } 12 \text { th-grade literacy class }\end{array}$ \\
\hline & ind 25 & $\begin{array}{l}\text { Teachers' expectancy } \rightarrow \text { student self-esteem } \rightarrow \text { student self- } \\
\text { expectancy } \rightarrow \text { time spent learning literacy } \rightarrow \text { the final marks in the } 12 \text { th- } \\
\text { grade literacy class }\end{array}$ \\
\hline & ind 26 & $\begin{array}{l}\text { Teachers' expectancy } \rightarrow \text { student self-expectancy } \rightarrow \text { the final marks in the } \\
\text { 12th-grade literacy class }\end{array}$ \\
\hline & ind 27 & $\begin{array}{l}\text { Teachers' expectancy } \rightarrow \text { student self-expectancy } \rightarrow \text { time spent learning } \\
\text { literacy } \rightarrow \text { the final marks in the } 12 \text { th-grade literacy class }\end{array}$ \\
\hline & ind 28 & $\begin{array}{l}\text { Teachers' expectancy } \rightarrow \text { time spent learning literacy } \rightarrow \text { the final marks in } \\
\text { the } 12 \text { th-grade literacy class }\end{array}$ \\
\hline & $\operatorname{dir} 4$ & Teachers' expectancy $\rightarrow$ the final marks in the 12th-grade literacy class \\
\hline
\end{tabular}

\section{Method}

\subsection{Sample}

The sample was organized in accordance with convenience-voluntary sampling scheme (Gravetter and Forzano 2010; Weathington et al. 2010). The sample included participants who: (1) provided a written consent to participate in the study; (2) were first-year students of humanities/social sciences (e.g. history, pedagogy, sociology etc.) or exact sciences/technical sciences (e.g. geology, physics, mathematics, etc.) and (3) graduated from high school and successfully passed the final exams (i.e. the matriculation tests) in the same calendar year when the study was conducted.

The study involved 1374 volunteers (682 women), first-year students (aged 19-20) of different faculties in the area of social sciences and humanities $(\mathrm{n}=701$; 355 women) and exact sciences/technical sciences $(n=673 ; 327$ women) of universities located in a large industrialised region of southeast Poland. The aims, 
procedure and materials used in the study have been approved by the Ethics Committee for Research at the Pedagogical University of Kraków.

\subsection{Materials}

Teachers' expectancy, student self-expectancy, and their self-esteem were assessed at the beginning of an academic year (October) by means of three questionnaires. Each questionnaire contained 6 statements (e.g. "My high school teachers were convinced I would manage to get admitted to technical studies" for teachers' expectancy; "Solving physics problems was always my Achilles' heel" for student self-esteem, and "Choosing a major I hoped I would be able to manage" for student self-expectancy) assessed on a scale from 1 to 4 , where 1 meant it was definitely inaccurate and 4 it was definitely accurate. The Cronbach's alphas for the abovementioned questionnaires were: $.766, .804$ and .593 , respectively. The total alpha for 18 items was .858. Compared to the first two measurement tools, the reliability level of the student self-esteem scale is relatively low. Hence, the results of path analyses containing this specified factor should be considered with caution.

After completing the questionnaires, respondents were asked to provide (1) matriculation test results in mathematics and literacy (equivalent to the Scholastic Assessment Test or American College Testing in the USA), taken 5 months earlier in high school (scale from 0 to 100 points, with a 30-point grade threshold); (2) marks obtained in the high school certificate in mathematics and literacy (on a scale from 1 to 6 , where 6 is the highest result); (3) average daily time (in minutes) spent learning mathematics and literacy prior to taking the matriculation test in these subjects; (4) sex; (5) age; and (6) study faculty and year.

\subsection{Procedure}

The study was conducted individually. The interviewer asked respondents to complete the questionnaires, informed respondents that the survey is anonymous and voluntary, and that it concerns circumstances related to their choice of field of study. If the participant requested additional information on these circumstances, the interviewer provided a standard answer pointing out such factors as the time spent learning various subjects, the student's own interests, the learning support received from last-grade secondary school teachers, etc. Thus, respondents were informed of the true purpose of the study without being given names of specific variables not to arouse demand characteristics (Orne 1962) that could influence their reactions.

Having obtained participation written consents, the interviewer gave the forms to the respondent and waited for him or her to complete them. Once the questionnaires had been completed, the interviewer checked whether all points had been evaluated. If any answeres were missing, the interviewer asked the respondent whether the omissions were intentional or not. If the respondent stated that the omission for various reasons was intentional, the interviewer did not pressure the respondent to explain, thanked him or her for participating in the study, and collected the completed questionnaires.

Direct and indirect teacher expectancy effects on students' outcomes were quantified in four multiple mediation analyses (cf. Figs. 1, 2, 3, 4), using the Process 


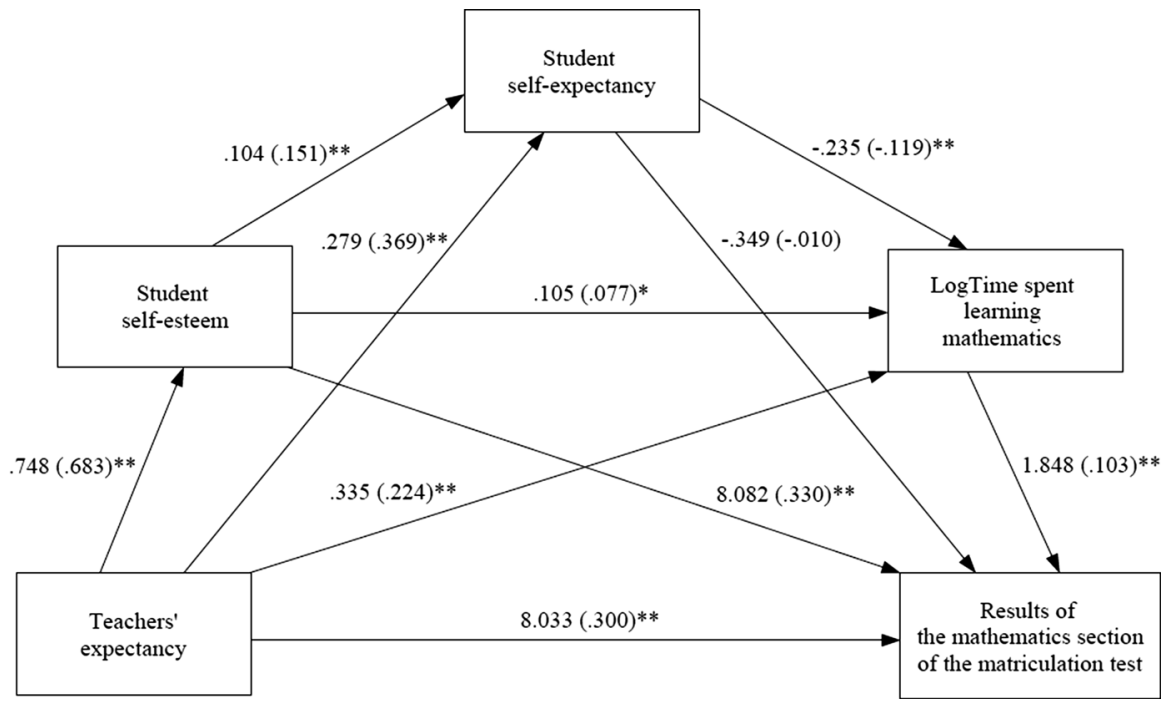

Fig. 1 A serial multiple mediation model with student self-esteem, student self-expectancy, and time spent learning mathematics as proposed mediators of teacher expectancy effects on results of the mathematics section of the matriculation test. Note: for each path two values are shown. The first refers to the unstandardised regression coefficient, whereas the second, in brackets, refers to the standardised regression coefficient. $\mathrm{R}^{2}=.364 ; \mathrm{MSE}=221.026 ; \mathrm{F}(4,1366)=195.244 ; p<.01 ; * p<.05 ; * * p<.01$

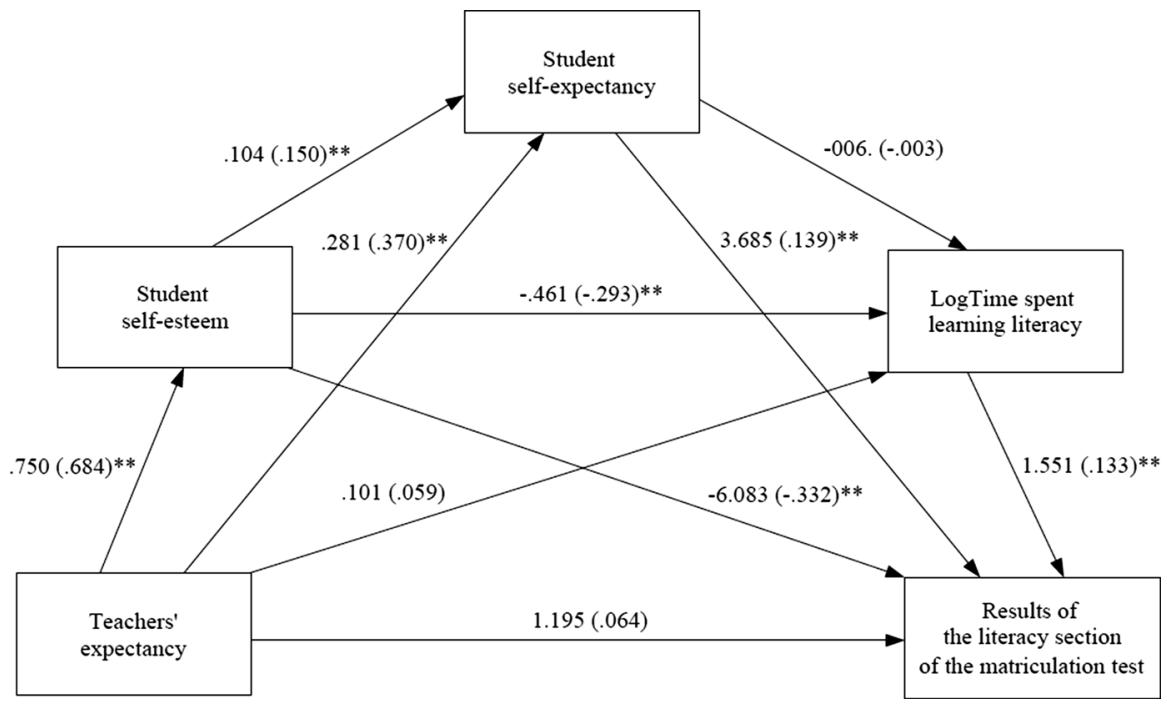

Fig. 2 A serial multiple mediation model with student self-esteem, student self-expectancy, and time spent learning literacy as proposed mediators of teacher expectancy effects on results of the literacy section of the matriculation test. Note: for each path two values are shown. The first refers to the unstandardised regression coefficient, whereas the second, in brackets, refers to standardised regression coefficient. $\mathrm{R}^{2}=.111 ; \mathrm{MSE}=173.252 ; \mathrm{F}(4,1369)=42.724 ; p<.01 ; * p<.05 ; * * p<.01$ 


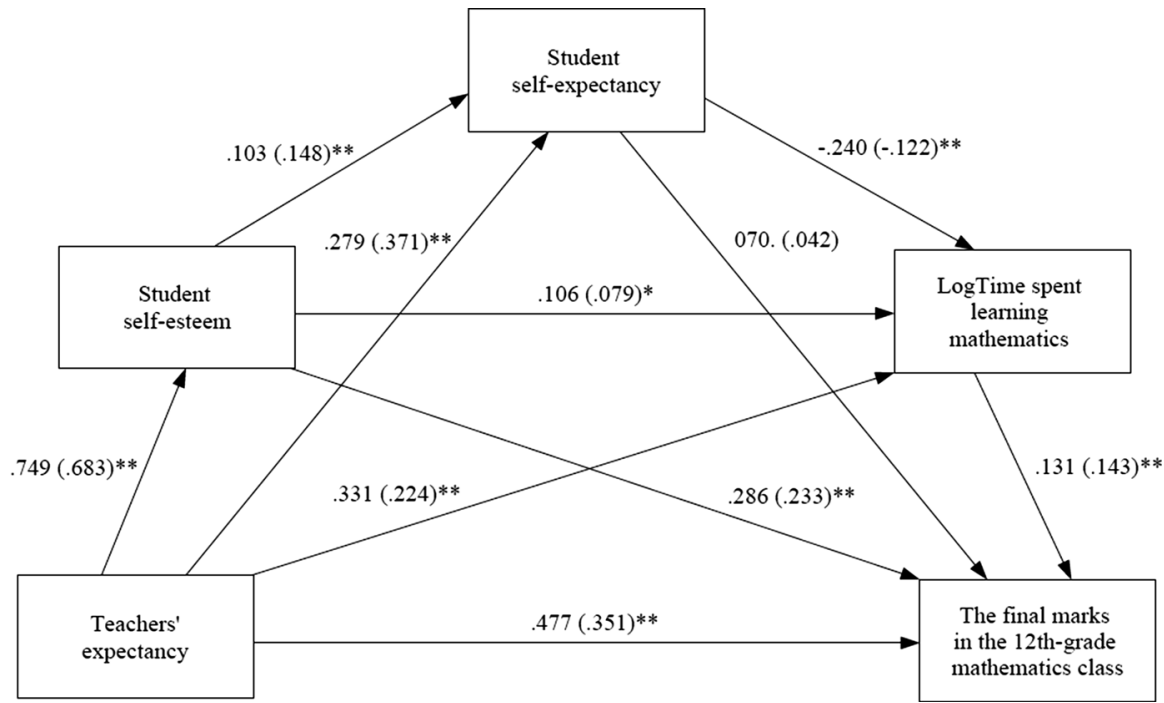

Fig. 3 A serial multiple mediation model with student self-esteem, student self-expectancy, and time spent learning mathematics as proposed mediators of teacher expectancy effects on the final marks in the 12th-grade mathematics class. Note: for each path two values are shown. The first refers to the unstandardised regression coefficient, whereas the second, in brackets, refers to standardised regression coefficient. $\mathrm{R}^{2}=.383 ; \mathrm{MSE}=.521 ; \mathrm{F}(4,1364)=211.341 ; p<.01 ; * p<.05 ; * * p<.01$

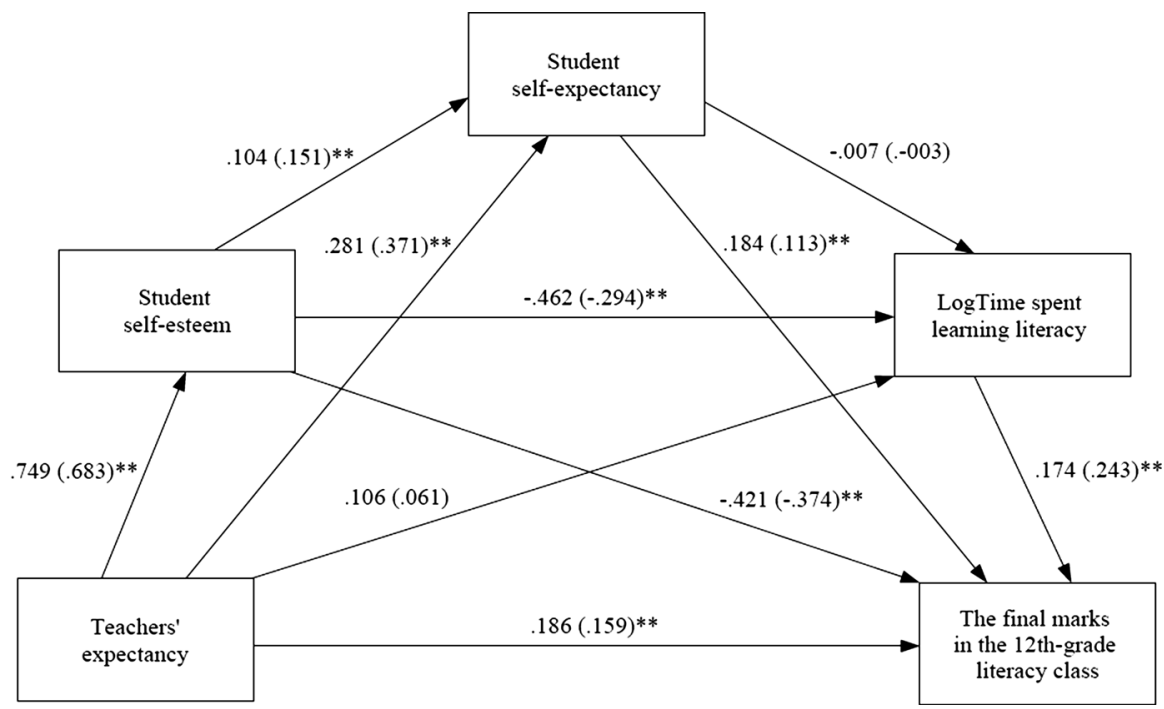

Fig. 4 A serial multiple mediation model with student self-esteem, student self-expectancy, and time spent learning literacy as proposed mediators of teacher expectancy effects on the final marks in the 12thgrade literacy class. Note: for each path two values are shown. The first refers to the unstandardised regression coefficient, whereas the second, in brackets, refers to standardised regression coefficient. $\mathrm{R}^{2}=.170 ; \mathrm{MSE}=.610 ; \mathrm{F}(4,1366)=70.054 ; p<.01 ; * p<.05 ; * * p<.01$ 
macro for SPSS (model 6 with four mediators), written by Hayes (2013). A biascorrected $95 \%$ confidence intervals based on 10,000 bootstrap samples were calculated for making statistical inferences about paths presented in the models $1-4$.

\section{Results}

\subsection{Preliminary data analysis}

Analysis of the distribution of variables presented in models 1-4 showed that, with the exception of time spent learning mathematics and literacy, and the results of the mathematics matriculation test, the distribution of other variables did not differ from the norm. Distributions of the first two were rightward skewed and the last was characterised by a flattened top.

Learning times were logarithmed in relation to results of the mathematics matriculation test, the logarithmic, square root, and arcsine transformation did not lead to normalisation of distribution. Taking into consideration the kurtosis and skewness values, the variable was ultimately left unchanged. Descriptive statistics are presented in Table 2.

To verify the heteroscedascisity assumption, the collinearity of antecedent variables presented in models 1-4 was quantified. For all models, VIF statistics $<2.08$, and tolerance $>.48$. Table 2 presents the results of correlation analysis for the quantified variables. Based on the analysis of standardised residuals (values over \pm 3.0 ) of sets of variables, 3, 5, 0, and 3 outliers were identified and eliminated from the sample, respectively for models 1-4. Therefore, depending on the conducted mediation analysis, the sample included 1371 (679 women), 1369 (679 women), 1374 and 1371 people (680 women). Finally, antecedent variables were centred on the mean, which enabled the interpretation of obtained results to make more sense, taking into consideration the fact that teachers' expectancy, student self-esteem, and their self-expectancy were quantified on scales without a zero point.

\subsection{Direct and indirect teacher expectancy effects on results of the matriculation test in mathematics}

Table 3 summarises the results of the quantification of paths presented in model 1.

Direct teacher expectancy effects $(b=8.033 ; p<.01)$ were stronger than the total indirect effects $($ effect $=6.532 ; p<.01)$. In the case of the direct effect, the increase in teachers' expectancy by one unit, with mediators staying at the same (average) level, improved results of the mathematics matriculation test by eight points. It follows that the change of teachers' expectancy from extremely negative to extremely positive resulted in an increase in test results by an average of 24 points. In the case of the indirect effect, an analogical improvement of teachers' expectancy resulted in an increase in test results by 19.5 points through the causal sequence from teachers' expectancy to student self-esteem, student self-expectancy 


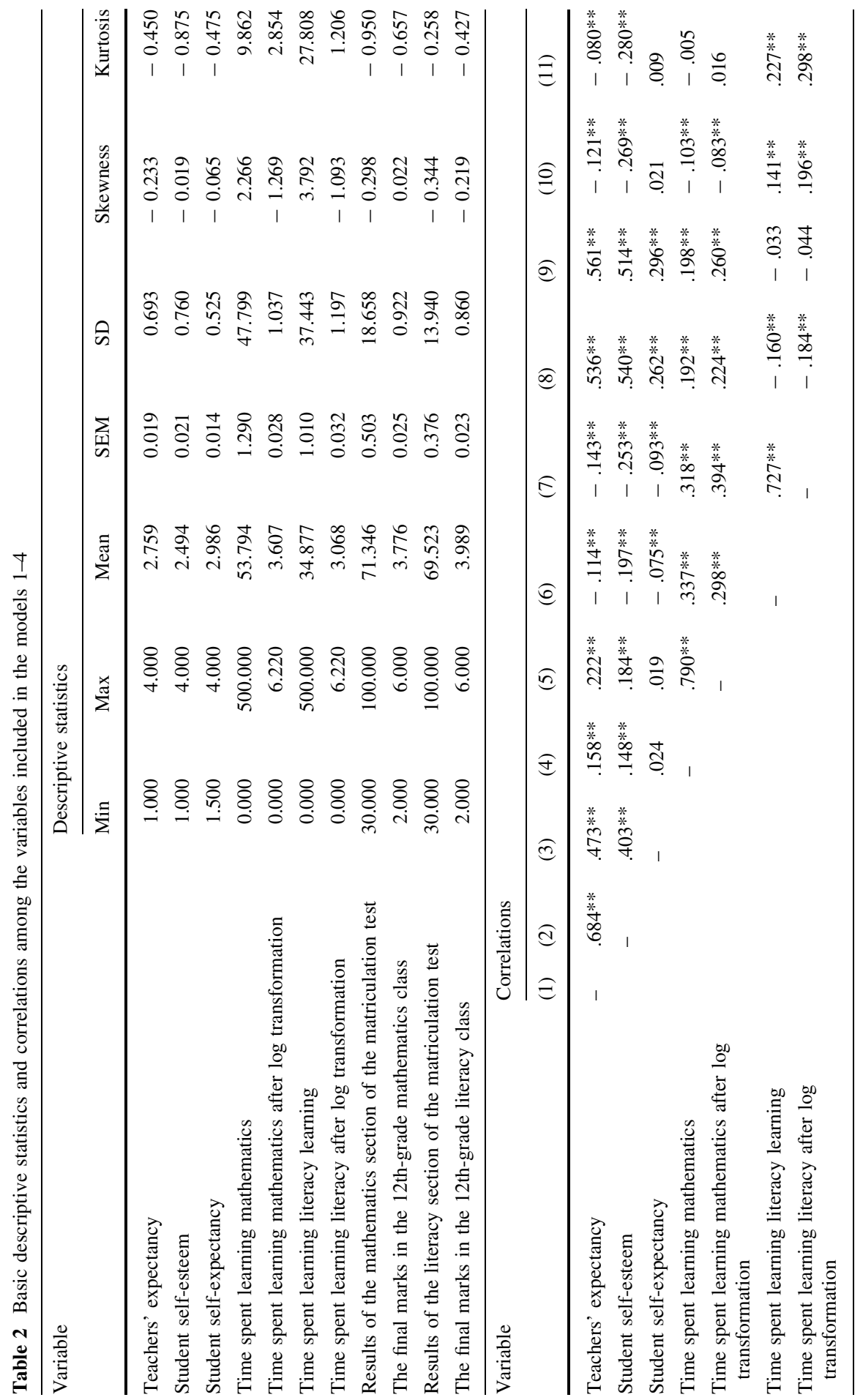




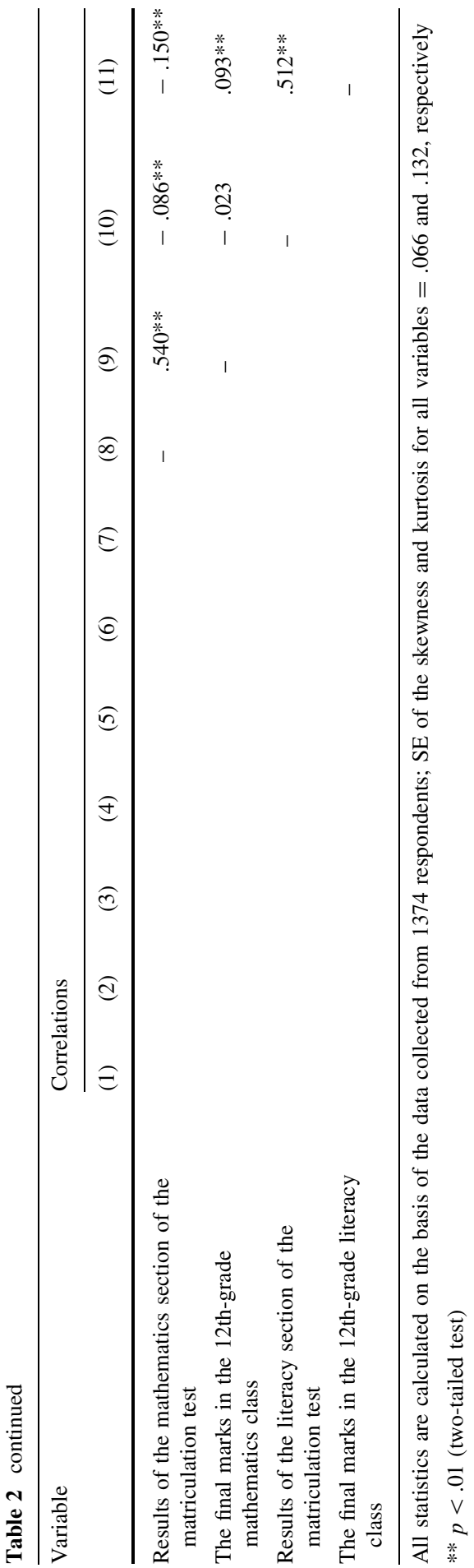




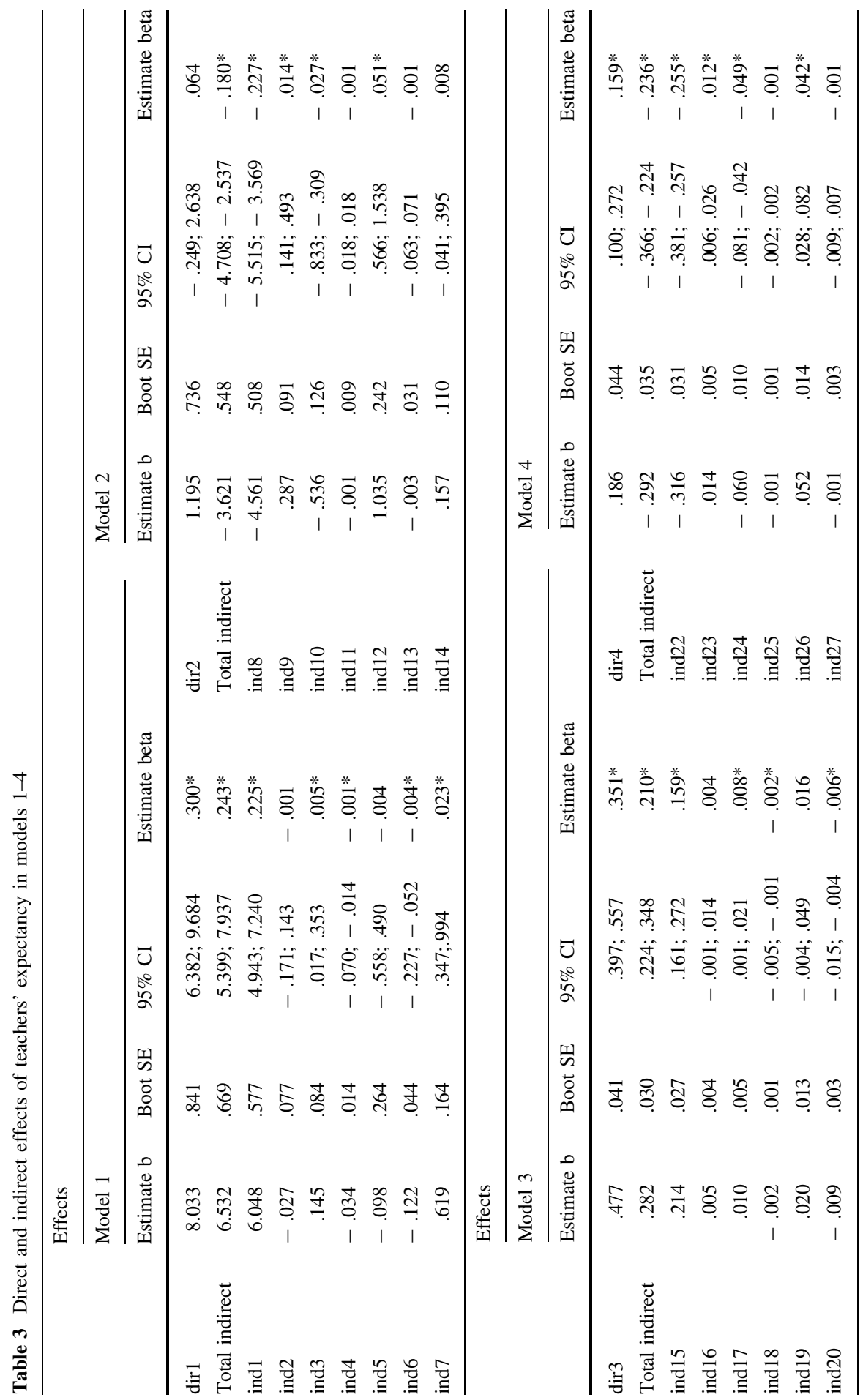




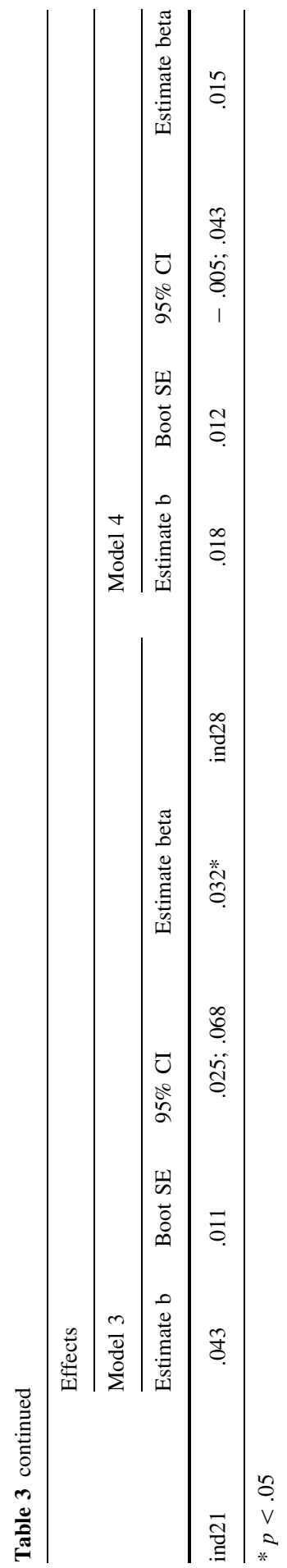


and time spent learning mathematics, and, in turn, through? these mediators to the results of the mathematics matriculation test.

Out of seven indirect paths, ind 2 and ind5 were insignificant due to the presence of student self-expectancy, whose direct influence on test results was marginal $(\mathrm{b}=-.349 ; \mathrm{p} n s)$. In contrast, the strongest mediator of the influence of teachers' expectancy on test results was student self-esteem (ind1) and learning time (ind7).

In the case of ind1, the improvement of teachers' expectancy by one unit led to a significant increase in student self-esteem by .748, which in turn was the source of improvement of test results by 6.048 points. In ind7, a similar improvement of teachers' expectancy led to an improvement of test results by .619 points, as a result of the earlier increase in learning time on average by $33 \%(b=.335 ; p<.01) .{ }^{1}$ Ind3, containing student self-esteem and learning time, can be interpreted analogically $($ effect $=.145 ; p<.01)$.

Negative indirect effects occurred in ind4 and ind6 due to the occurrence of negative relations between student self-expectancy and learning time and test results $(\mathrm{b}=-.235 ; p<.01$ and $\mathrm{b}=-.349 ; p<.01$, respectively). In ind 4 , an increase in teachers' expectancy by one unit paradoxically lowered test results by .034 points, as a result of the earlier changes in student self-esteem, their self-expectancy, and learning time; and in ind6, a similar improvement in teachers' expectancy lowered test results by .122 points, as a consequence of changes in student selfexpectancy and learning time.

\subsection{Direct and indirect teacher expectancy effects on results of the matriculation test in literacy}

Table 3 shows the results of the quantification of paths presented in model 2. Direct teacher expectancy effects were insignificant $(\mathrm{b}=1.195 ; p=.105)$ in contrast to the negative total indirect effect (effect $=-3.621 ; p<.01$ ). This means that the change of teachers' expectancy from extremely negative to extremely positive was the source of a decrease in the results of the literacy matriculation test by approximately 11 points, as a consequence of the change of mediators and their feedback influence on test results.

The greatest negative indirect influence was presented by ind8-the students in relation to whom teachers' expectancy were higher by one unit were characterised by greater self-esteem $(\mathrm{b}=.750 ; p<.01)$, which unexpectedly lowered test results by 4.561 points. The negative influence of student self-esteem on test results was mediated by literacy learning time - an improvement in student self-esteem, caused by the earlier increase in teachers' expectancy, was the source of an approximately $46 \%$ decrease in learning time $(\mathrm{b}=.461 ; p<.01)$, which in turn lowered test results by .536 points.

In contrast, in ind12, the literacy matriculation test of students in relation to whom teachers' expectancy was higher by one unit increased by 1.035 points, as a result of the earlier improvement of student self-expectancy $(b=.281 ; p<.01)$. In ind9, a similar increase in teachers' expectancy led via the causal sequence to the

\footnotetext{
${ }^{1}$ For the log-linear model, each 1-unit increase in antecedent variable multiplies the expected value of Y by $e^{\mathrm{b}}$ or $100^{*} \mathrm{~b}$; cf. Benoit (2011).
} 
improvement of student self-esteem $(\mathrm{b}=.749 ; p<.01)$ and their self-expectancy $(\mathrm{b}=.104 ; p<.01)$, which in turn increased test results by .287 points.

\subsection{Direct and indirect teacher expectancy effects on final marks in mathematics}

Table 3 showing the results of the quantification of paths presented in model 3. Direct teacher expectancy effects were stronger $(b=.477 ; p<.01)$ than the total indirect effect (effect $=.282 ; p<.01)$. It follows that the change of teachers' expectancy by one unit, with mediators staying at the same (average) level, caused an increase in final marks in mathematics by .5 of a grade. In the case of the indirect effects, a similar increase in teachers' expectancy caused an improvement of final marks by approximately .25 of a grade.

Due to the marginal importance of student self-expectancy $(b=.070 ; p=.10)$, ind16 and ind19 were insignificant. The greatest indirect influence of teachers' expectancy was presented by ind15. An improvement of student self-esteem $(\mathrm{b}=.749 ; p<.01)$, as a result of the earlier increase in teachers' expectancy by unit, increased final marks by .214 of a grade, and in ind 21 , a $33 \%$ increase in

Table 4 Size of indirect, direct and total effects of teachers' expectancy on four consequent variables

\begin{tabular}{lllll}
\hline & Consequent variables & & \\
\cline { 2 - 5 } & $\begin{array}{l}\text { Results of the } \\
\text { mathematics section } \\
\text { of the matriculation } \\
\text { test }\end{array}$ & $\begin{array}{l}\text { Results of the } \\
\text { literacy section of } \\
\text { the matriculation } \\
\text { test }\end{array}$ & $\begin{array}{l}\text { The final marks in } \\
\text { the 12th-grade } \\
\text { mathematics class }\end{array}$ & $\begin{array}{l}\text { The final marks } \\
\text { in the 12th-grade } \\
\text { literacy class }\end{array}$ \\
\hline $\begin{array}{c}\text { Partially } \\
\text { standardized } \\
\text { indirect } \\
\text { effect }\end{array}$ & .339 & -.247 & .289 & -.337 \\
$\begin{array}{c}\text { Partially } \\
\text { standardized } \\
\text { direct effect }\end{array}$ & .439 & & & .233 \\
$\begin{array}{c}\text { Partially } \\
\text { standardized } \\
\text { total effect }\end{array}$ & .778 & .094 & .513 & -.104 \\
$\begin{array}{c}\text { Completely } \\
\text { standardized } \\
\text { indirect } \\
\text { effect }\end{array}$ & .243 & -.153 & .802 & -.236 \\
$\begin{array}{c}\text { Completely } \\
\text { standardized } \\
\text { direct effect }\end{array}$ & .300 & & & \\
$\begin{array}{c}\text { Completely } \\
\text { standardized } \\
\text { total effect }\end{array}$ & .543 & -.180 & .210 & \\
\hline
\end{tabular}

All values presented in the table refer to the standardised regression coefficient 
learning time of mathematics $(\mathrm{b}=.331 ; p<.01)$, caused by an analogical improvement of teachers' expectancy, led to an increase in final marks by .043 of a grade.

Paths ind18 and ind20, containing student self-expectancy, were negativeimprovement of teachers' expectancy by unit lowered final marks by .002 and .009 points, respectively, due to a negative relation between student self-expectancy and learning time $(\mathrm{b}=-.240 ; p<.01)$. High student self-expectancy inclined students to invest less time in learning mathematics, which in turn led to obtaining lower marks in this subject.

\subsection{Direct and indirect teacher expectancy effects on final marks in literacy}

Table 3 summarises the results of the quantification of paths presented in model 4 . The direct effect was weaker $(b=.186 ; p<.01)$, and its direction opposite compared to the total indirect teacher expectancy effects (effect $=-.292$; $p<.01)$. With respect to the former, it can be assumed that among students characterised by a similar (average) level of self-esteem, self-expectancy, and literacy learning time, an improvement of teachers' expectancy by unit resulted in an increase in final marks in literacy by .186 of a grade. In the case of the latter, an analogical increase in teachers' expectancy unexpectedly lowered final marks by .292 of a grade, as a result of the effect of teachers' expectancy on the indicated mediators, which in turn affected the final marks.

The strongest mediator of the teachers' expectancy effect was student selfesteem. In ind22, students given teachers' expectancy higher by one unit were characterised by a more positive self-esteem $(b=.749 ; p<.01)$, which in turn lowered final marks by .316 of a grade. The negative influence of student selfesteem on the marks was mediated by literacy learning time (ind24)-improvement of student self-esteem, caused by the earlier increase in teachers' expectancy, was a source of a $17 \%$ decrease in learning time $(b=.174 ; p<.01)$, which in turn lowered final marks by .06 of a grade.

Positive indirect effects occurred in the case of paths containing student selfexpectancy. In ind26 (effect $=.052 ; p<.01)$, its improvement $(\mathrm{b}=.281 ; p<.01)$, caused by an increase in teachers' expectancy by unit, in turn led to an increase in final marks by .281 of a grade. Finally, in ind23, a similar increase in teachers' expectancy led to the improvement of final marks by .014 of a grade, as a result of the earlier increase through casual sequence in student self-esteem and their selfexpectancy $(b=.749$ and.104; both $p<.01)$.

\subsection{Direct and indirect effect size}

In order to compare the effect size of teachers' expectancy, the partially and completely standardised teacher expectancy effects on each consequent variable (Hayes 2013) were calculated. The obtained results are presented in Table 4. 
The greatest mediated effect size of teachers' expectancy occurred in reference to test results in mathematics and final marks in literacy (negative), and then final marks in mathematics and test results in literacy (negative). Taking into consideration the values of partially/completely standardised indirect effects yielded for test results in mathematics, it can be concluded that an increase in teachers' expectancy by one point on a scale/1 SD, resulted in an improvement of test results in mathematics by $.339 \mathrm{SD} / 232 \mathrm{SD}$ as a result of teacher expectancy effects on student self-esteem, their self-expectancy and mathematics learning time in the causal chain, which in turn affected test results. In contrast, in the case of final marks in literacy, an increase in teachers' expectancy by one point on a scale/1 SD improved marks by $.337 \mathrm{SD} / .231 \mathrm{SD}$ as a result of the earlier changes of mediators, which negatively affected the students' grades. The effect size of other consequent variables should be interpreted analogously.

The greatest direct teacher expectancy effects were discovered in the case of final marks and test results in mathematics, and then final marks and test results in literacy. Regardless of an indirect mechanism, an increase in teachers' expectancy by unit/1 SD was the cause of an improvement of consequent variables by $.513 \mathrm{SD} /$ $.351 \mathrm{SD}, .439 \mathrm{SD} / .300 \mathrm{SD}, .233 \mathrm{SD} / 159 \mathrm{SD}$, and .094 SD/.064 SD, respectively.

Finally, taking into consideration the total impact of teachers' expectancy, the greatest effect size was discovered for final marks and test results in mathematics, and then test results and final marks in literacy (both negative). With respect to final marks in mathematics, an improvement of teachers' expectancy by unit/1 SD caused an increase in the indicated variable by $.802 \mathrm{SD} / .449 \mathrm{SD}$ among students characterised by more positive self-esteem, more negative self-expectancy, and a higher mathematics learning time. The total effect size for the remaining variables should be interpreted analogically, bearing in mind the indirect paths signs.

\section{Discussion of results}

The aim of this study was to test four mediation models involving the association of teachers' expectancy with students' mathematics and literacy outcomes through: (1) student self-esteem; (2) their self-expectancy; and (3) time spent learning mathematics and literacy.

First, the findings revealed that the direct teacher expectancy effects were significant and positive for all controlled students' outcomes, i.e.: mathematics and literacy test results as well as marks in mathematics and literacy. Second, the total indirect teacher expectancy effects were significant, but their signs varied in specific curriculum areas. Third, the importance of mediators, i.e., the order of meditators' significance in the frame of tested models, depended on specific curriculum areas. 


\subsection{Direct and indirect teacher expectancy effects on students' mathematics and literacy outcomes}

In this study, the direct teacher expectancy effects were stronger than the total indirect effects in the case of mathematics outcomes-both test results and the students' marks. In contrast, for test results and students' marks in literacy, the total indirect effects were stronger than the direct teacher expectancy effects.

The patterns observed could be explained as follows. Effective learning of abstract, often complicated language used in mathematics, e.g., matrix algebra, probability theory, differential calculus, etc., covered in the last grade of secondary school in Poland, may require more support from a teacher than practising native language during literacy classes. Hattie (2008) emphasises that practising complicated skills independently does not make the practitioner a master automatically, and therefore, not necessarily translates into positive learning effects. Deep, deliberative student activity is necessary to be? organised by teachers and parents.

According to van Gogh et al. (2005) such type of activity, characterised by an appropriate level of difficulty, motivates students to make an effort by being challenging. On the other hand, it allows them to train acquired skills systematically, creating space to commit and correct their mistakes, and receive constructive feedback. This type of activity engages the learner's attention for longer, which allows the learner to process the contents taught during classes on multiple levels, and as a result, understand and memorise it better.

Assuming this is true, teachers during mathematics classes may transmit their expectancy to students directly by learning and emotional support factors to a greater extent than during literacy classes (Babad 2009; Good and Brophy 2008; Rosenthal 1989). Stronger direct teacher expectancy effects for mathematics outcomes compared to indirect effects were also reported by others (c.f. Jussim 1989; Jussim and Eccles 1992; Gill and Reynolds 1999).

Similarly, in the case of the impact of teachers' expectancy on test results versus marks, obtained findings are consistent with the results of other studies (c.f. Jussim et al. 1996; Madon et al. 1997; Smith et al. 1999). Stronger effects have been recorded in the case of students' marks that are more susceptible to the influence of the teachers' subjective preferences than the results of standardised tests. On the other hand, considering that in terms of students' literacy outcomes, the indirect teacher expectancy effects are stronger than direct ones, it is hard to explain the obtained results in a rational way by reference to the other authors' results. For instance, in studies conducted by Gill and Reynolds (1999) as well as Kuklinski and Weinstein (2001), direct relations between teachers' expectancy and students' reading outcomes were distinctively stronger, and often significant, when compared to relations mediated by "child perceptions of teacher expectations" and "children's self-expectations in reading," respectively, that were often insignificant.

Perhaps the obtained results are specific to the Polish sample covering final-grade high school students, i.e., subjects aged 18 years old, just before important exams for their educational and professional career. The results presented by Gill and Reynolds (1999) and Kuklinski and Weinstein (2001) concerned elementary school students, who perhaps have less crystallised self-esteem, self-expectancy, or other 
motivational variables important for the mediation of teachers' expectancy (Dweck 2002; Eccles and Wigfield 1985; Schunk and Zimmerman 2009; Wigfield and Eccles 2000).

Moreover, it cannot be ruled out that these results are an artefact resulting from the method used in this study or various uncontrollable confounding variables significant for learning outcomes, especially for literacy outcomes, and at the same time, interacting with mediators, i.e., student self-esteem, their self-expectancy, or time spent learning specific curriculum areas. One such uncontrollable moderator could be "achievement values", which includes: attainment value or importance, intrinsic value, and utility value or usefulness of the task (Wigfield and Eccles 2000), reversing the direction of relationship between students' self-esteem and literacy outcomes.

As Wigfield and Eccles (2000) claim, "utility value or usefulness of the test refers to how a task fits into an individual's future plans, for instance, taking a mathematics class to fulfil the requirement for a science degree. Cost refers to how the decision to engage in one activity (e.g., doing schoolwork) limits access to other activities (e.g., calling friends), assessments of how much effort will be taken to accomplish the activity, and its emotional cost" (p. 74).

Taking into account the gross enrolment ratio in Poland (World Bank data 2017; Ministry of Science and Higher Education in Poland 2013) and a significantly higher number of unemployed graduates of humanities/social sciences than those of science/technology (Turek 2011), the value attributed to literacy learning could be lower than the one attributed to mathematics learning, which is perceived as a means to undertake prestigious engineering studies, and then to find a well-paid, prospective job. In turn, differences in the intrinsic value of literacy versus mathematics in interaction with the self-esteem variable could enhance a positive versus negative reaction between teachers' expectancy and students' outcomes in mathematics and literacy, respectively. However, this interpretation is speculative because the impact of outcome values on the relations between student self-esteem/ student self-expectancy and outcomes in mathematics and literacy were not assessed in this study.

However, in defence of the obtained results, it may be useful to point out the rationales that the influence of teachers' expectancy on students' literacy outcomes could be pursued by indirect paths to a greater extent than by the direct ones. For example, Kuklinski and Weinstein (2001) revealed that the indirect influence of teacher expectations on children's reading outcomes through their self-expectancy in reading was particularly salient in classes with a high PDT (perceived differential treatment) index and among older students. Furthermore, the increase in magnitude of the indirect effect was accompanied by a significant decrease in the direct effect. Assuming a linear change in proportion of the direct to indirect effect, in the last grades of high school, it can be predicted that indirect relations between teacher expectations and students' literacy outcomes will be stronger than direct ones. 


\subsection{The size of the total teacher expectancy effects on students' mathematics and literacy outcomes}

Analyses revealed that the total teacher expectancy effects were the strongest for marks, and then for test results in mathematics, test results, and marks in literacy. Results similar to these regarding student mathematics outcomes were obtained by Jussim (1989) and Jussim and Eccles (1992), Madon et al. (1997) and Smith et al. (1999).

The above authors revealed that the strength of the paths connecting teachers' perception of student performance, effort or talent, and students' mathematics outcomes ranged from $\beta=.10$ (Smith et al. 1999), through $\beta=.19 / .20$ (Jussim 1989; Jussim and Eccles 1992, respectively), to $\beta=.49$ (Smith et al. 1999) for marks, and ranged from $\beta=.09$ (Smith et al. 1999), through $\beta=.16 / .17$ (Smith et al. 1999; Jussim 1989, respectively), to $\beta=.21$ (Jussim and Eccles 1992) for test results. Moreover, in the cited studies, the power of the tested relations decreased with students who moved from lower to upper classes, and was, on average, higher for marks more susceptible to teachers' perceptual bias than standardised tests (Smith et al. 1999).

Similarly, other authors using different samples than Jussim et al. reported either weaker relations between teachers' expectations and students' mathematics outcomes, e.g., $\beta=.14$ (Speybroeck et al. 2012) and $\beta=.20$ (Hinnant et al. 2009) or comparable with and even higher than values quantified in meta-analyses (Hattie 2008; Rosenthal 1997), e.g., $\beta=.40$ (Gill and Reynolds 1999).

Due to the salient and negative relations between student self-esteem and consequent variables, the total teacher expectancy effects on the test results and students' marks in literacy were negative. Reported results may be surprising and difficult to explain in the light of influential theories (Dweck and Master 2009; Wigfield and Eccles 2000; Urhahne and Zhu 2016), results of studies (e.g., Stevenson and Newman 1986; Meece et al. 1990), and meta-analyses (Hattie 2008). Other authors who analysed analogous relations usually reported positive effects, e.g., Kuklinski and Weinstein (2001) $\beta=.35$ and .22, respectively, for primary grades 3 and 5 with a higher PDT index, and Garrett et al. (2015) $\eta^{2}=.11$, for elementary school students.

To summarise, the discovered magnitudes of the total teacher expectancy effects on test results and marks in mathematics were medium $(\beta=.532$ and .549 , respectively) and within the limits reported by other authors. On the other hand, assuming that the results obtained for the test results and marks in literacy are not accidental, their magnitudes were small ( $\beta=-.116$ and -.077 , respectively) and deviated less than those presented in other studies.

\subsection{The order of mediators' importance in relations between teachers' expectancy and students' outcomes in mathematics and literacy}

Teachers' expectancy was most intensively mediated by student self-esteem, and then-depending on the outcome area-time spent learning and student selfexpectancy (mathematics), or self-expectancy and time spent learning (literacy). 
The role of self-esteem and self-expectancy was equivocal-for outcomes in mathematics, self-esteem was a positive and self-expectancy was a negative mediator, whereas for literacy, self-expectancy was a positive and self-esteem was a negative mediator. In contrast, the effect of time was always positive-its increase was associated with improvement in outcomes in mathematics and literacy.

The obtained results seem to be consistent with the findings of Bandura (1997), who made a distinction between an individual's beliefs that he/she can accomplish a task, i.e., self-esteem in various domains of school activity, and the belief that a given action will lead to a given outcome, i.e., self-expectancy on various domains of school activity, and highlighted that the first factor is more predictive of performance than the second factor.

Self-esteem seems to be a more tangible factor, referring to the students' current experiences, e.g., beliefs such as "I know I'm a great interpreter of Franz Kafka's prose" or "I can solve trigonometric functions because on the last test I got an A grade." In contrast, self-expectancy may concern a more or less vague future, e.g., beliefs such as "I can handle my dream university programme in geodesy/ archaeology, and even advanced classes, which I might only have a modest understanding of".

Furthermore, according to Deci and Ryan's (1985) and Ryan's (1992) selfdetermination theory, the need for competence motivates people to seek out the optimal stimulation and/or challenging activities. In this light mathematics and literacy learning could provide various types of stimulation. Therefore, it is impossible to exclude different strengths and directions of relations between mathematics and literacy outcomes and self-esteem versus self-expectancy for test results and the students' marks.

Assessing students in mathematics or literacy is a fixed point of school reality, both on an elementary and secondary level (Good and Brophy 2008; Babad 2009). Instead, the result of the matriculation test, as opposed to partial school grades received on a daily basis, is more consequential for the further educational career of students, i.e., the possibility to choose a more or less prestigious field of study. Hence, the impact of student self-esteem/self-expectancy on the results of the mathematics and literacy matriculation test should be stronger than on final marks in the same curriculum sections. The same arguments explain the observed differences in the strength of relations between student self-esteem/self-expectancy and time spent learning for models of marks and test results in mathematics and literacy.

Finally, the interpretation of the role of time spent learning mathematics and literacy is not as difficult as in the case of the mediators discussed above. Regardless of the tested model, learning time had a positive impact on students' outcomes, wherein the recorded average effect size $(\beta=.109)$ was lower than those reported in the meta-analyses $(d=.38$; c.f. Hattie 2008).

\subsection{Magnitude and direction of student self-expectancy and teacher expectancy effects on students' mathematics and literacy outcomes}

The teacher expectancy effects were stronger than student self-expectancy for the test results and marks in mathematics (ratio $=23.017$ and 6.814 , respectively), the 
same in relation to marks in literacy (ratio $=1.010)$, and weaker in relation to test results in literacy (ratio $=.324$ ). The positive direction of the direct effect of both variables occurred in the case of outcomes in literacy. Considering outcomes in mathematics, teacher expectancy effects were positive and student self-expectancy insignificant.

In terms of the quantified ratio for mathematics, the obtained results are comparable to the findings of other studies. The teacher expectancy effects and student self-expectancy for mathematics outcomes reported by Gill and Reynolds (1999) were $\beta s=.40$ and .12 , respectively, hence, ratio $=3.333$. On the other hand, an average beta calculated based on data gathered by Entwisle et al. (1988, see Table 2, p. 182) regarding the relation between student self-expectancy and their mathematics outcomes, was -.024 . Compared to the average magnitude of teacher expectancy effect of .20 computed in meta-analyses (Jussim and Harber 2005), the Entwisle's result provides the ratio $=8.33$.

In contrast, the ratio of magnitudes of the direct teacher expectancy effects and student self-expectancy for their literacy outcomes obtained in this investigation may be surprising, considering the Gill and Reynolds (1999) as well as Kuklinski and Weinstein (2001) studies. The result of the first ratio was 3.23, and results of the second ratio were 2.91 and 2.11, respectively, for grades 3 and 5 with high PDT indexes. The unexpected low value of the ratio can be explained by the specificity of the Polish sample, which included first-year students reporting their educational experiences from the last grade at high school rather than elementary school students as in the aforementioned studies.

As acknowledged in Sect. 4.1, the differences in ratios for the indicated curriculum areas can be explained by a variation in the level of expectancy-tinged emotional and substantive support given by teachers to students, which is required for effective learning of more or less abstract and complicated contents of mathematics and native language, respectively (Babad 2009; Good and Brophy 2008; Hattie 2008), taught in the last grade of high school in Poland. Assuming this is true, the direct teacher expectancy effects for students' mathematics outcomes should be more salient than the effects of student self-expectancy, while for literacy outcomes these differences should tend to disappear.

On the other hand, it cannot be ruled out that the surprisingly low ratios for students' literacy outcomes were accidental or resulted from interaction between student self-expectancy and the preceding variable, i.e., student self-esteem, or other potential moderators such as value placed on literacy skills by women versus men who are more willing to study technology/science versus humanities/social sciences (Wigfield and Eccles 2000).

\section{Limitations, conclusions, and recommendations}

The quantified models 1-4 fit the data and explained $11-38 \%$ of variances in students' outcomes. This does not mean, however, that the considered paths were necessarily causal, as assumed. The variables in the study were not manipulated but quantified in a retrospective, questionnaire-based assessment. This limitation is 
mentioned by other authors (e.g., Bizer et al. 2012; Krieger and Sarge 2013; Speybroeck et al. 2012), who quantify mediation models in accordance with the approach proposed by Hayes (2013).

The second limitation of the study was that time spent learning mathematics and literacy was declared by students a few months after passing the matriculation test and not measured by them on a daily basis over a period of 8 months during the final grade in high school. However, even in such methodologically inflated conditions, students could purposefully over- or understate a learning time estimate, e.g., to increase self-esteem (presenting oneself in a positive light versus handicapping strategy, cf. Rhodewalt 2008; Trzesniewski et al. 2010). In addition, the study did not control a number of confounding variables that could determine the direction and/or size of the direct and indirect teacher expectancy effects, e.g., by random assignment of people to experimental conditions. The problem of omitted variables is typical of correlational studies (cf. Madon et al. 1997; Smith et al. 1999).

Undoubtedly, longitudinal studies, in which selected antecedent variables are additionally manipulated, are a source of high quality data, based on which the causal models of phenomena can be tested more accurately than in questionnairebased studies (de Boer et al. 2010; Smith et al. 1999). However, in relation to some variables, e.g., student self-esteem and self-expectancy, intentionally decreasing or increasing their level, especially in the final grade of high school just before one of the most important exams in their life, would be ethically reprehensible. Therefore, in the conducted study the values of variables were quantified a few months after the exams.

Third, as Wigfield and Eccles (2000) claimed, the variable measuring method adopted in a particular study may return different estimates. The authors argue "the definition of these constructs (i.e., ability and student expectancy beliefs) varies across theoretical perspectives. Measures of these beliefs also vary across theory, especially with respect to their specificity and exactly what aspects of ability are asked about" (p. 72). The same argument also applies to other variables included in the study, i.e., student self-esteem, their self-expectancy, etc. It cannot be ruled out that operationalisations adopted here could be related to a different aspect of variables compared to aspects quantified by other authors. Hence, the results reported by them could differ significantly (e.g., Jussim and Eccles 1992; Gill and Reynolds 1999; Madon et al. 1997; Smith et al. 1999; Speybroeck et al. 2012).

The fourth limitation concerns the reliability of measuring the student selfexpectancy variable. It is worth recalling the objections concerning the level of consistency of the scale used to estimate it. Therefore, the results obtained for indirect paths containing the indicated factor should be interpreted with caution.

Finally, the obtained results showed that an analysis of teacher expectancy effects, which confines itself to the evaluation of direct teacher expectancy effects on students' outcomes, might distort an image of this phenomenon. A positive direct teacher expectancy effects does not guarantee that the effects mediated by students' individual differences will also be positive. In other words, an increase in teachers' expectancy may lead to the improvement of educational outcomes, and, at the same 
time, by affecting selected qualities of students, e.g., their self-esteem and/or selfexpectancy, it may paradoxically result in their decrease.

The revealed expectancy effects have practical implications. It is worth recalling that in the analysed sample, the average gap in the results of the mathematics and literacy matriculation test of the extremely high versus extremely low expectancystudents was approximately 2.33 and $-.46 \mathrm{SD}$, respectively, which corresponded to approximately 44 points increase and 7 points decrease of the test, while the grade threshold in Poland for both subjects is 30 points. On the other hand, for final marks in mathematics and literacy, the average gap between the mentioned groups of students was approximately 2.40 and $-.30 \mathrm{SD}$, respectively, which corresponded to approximately a 2.5 grade increase and a .3 grade decrease, while the Polish scale of marks for both subjects has 6 grades. Therefore, it is clear that the impact of teachers' expectancy was especially strong for mathematics outcomes, inconsistent (i.e., positive vs negative for direct and indirect effects, respectively), and could be decisive for students' educational career, i.e. their chances of passing the abovementioned exams as well as graduating with satisfactory grades in mathematics and literacy, and consequently, their opportunity to choose among less or more prestigious fields of study.

Acknowledgements This work was supported by the National Science Centre in Poland (Grant Number 2012/05/D/HS6/03350).

\section{Compliance with ethical standards}

Conflict interest The author declares that there is no conflict of interest.

Open Access This article is distributed under the terms of the Creative Commons Attribution 4.0 International License (http://creativecommons.org/licenses/by/4.0/), which permits unrestricted use, distribution, and reproduction in any medium, provided you give appropriate credit to the original author(s) and the source, provide a link to the Creative Commons license, and indicate if changes were made.

\section{References}

Babad, E. (2009). The social psychology of the classroom. New York: Routledge.

Babad, E., Inbar, J., \& Rosenthal, R. (1982). Pygmalion, Galatea, and the Golem: Investigations of biased and unbiased teachers. Journal of Educational Psychology, 74, 459-474.

Bąbel, P., \& Trusz, S. (2016). Expectancy effects: An attempt to integrate intra- and interpersonal perspectives. In S. Trusz \& P. Bąbel (Eds.), Intrapersonal and interpersonal expectancies (pp. 162-178). New York: Routledge.

Bandura, A. (1997). Self-efficacy: The exercise of control. New York: W. H. Freeman.

Baumaister, R. F., Campbell, J. D., Krueger, J. I., \& Vohs, K. D. (2003). Does high self-esteem cause better performance, interpersonal success, happiness, or healthier lifestyles? Psychological Science in the Public Interest, 4, 1-44.

Benoit, K. (2011). Linear regression models with logarithmic transformations. http://www.kenbenoit.net/ courses/ME104/logmodels2.pdf. Accessed April 27, 2017.

Bizer, G. Y., Hart, J., \& Jekogian, A. M. (2012). Belief in a just world and social dominance orientation: Evidence for a mediational pathway predicting negative attitudes and discrimination against individuals with mental illness. Personality and Individual Differences, 52, 428-432. 
Blanck, P. D. (Ed.). (1993). Interpersonal expectations: Theory, research, and applications. New York: Cambridge University Press.

Brattesani, K., Weinstein, R. S., \& Marshall, H. H. (1984). Student perceptions of differential teacher treatment as moderators of teacher expectation effects. Journal of Educational Psychology, 76, 236-247.

Brophy, E. (1985). Teacher-student interaction. In J. B. Dusek (Ed.), Teacher expectancies (pp. 303-328). Hillsdale, NJ: LEA.

Cooper, H. (1985). Models of teacher expectation communication. In J. B. Dusek (Ed.), Teacher expectancies (pp. 135-158). Hillsdale, NJ: LEA.

Cooper, H., \& Hazelrigg, P. (1988). Personality moderators of interpersonal expectancy effects: An integrative research review. Journal of Personality and Social Psychology, 55, 937-949.

Darley, J. M., \& Fazio, R. H. (1980). Expectancy confirmation processes arising in the social interaction sequence. American Psychologist, 35, 867-881.

de Boer, H., Bosker, R. J., \& van der Werf, M. P. C. (2010). Sustainability of teacher expectation bias effects on long-term student performance. Journal of Educational Psychology, 102, 168-179.

Deci, E. L., \& Ryan, R. M. (1985). Intrinsic motivation and self-determination in human behavior. New York: Plenum.

Dusek, J. B. (Ed.). (1985). Teacher expectancies. Hillsdale, NJ: LEA.

Dusek, J., \& Joseph, G. (1983). The bases of teacher expectancies: A meta-analysis. Journal of Educational Psychology, 75, 327-346.

Dweck, C. S. (2002). Messages that motivate: How praise molds students' beliefs, motivation, and performance (in surprising ways). In J. Aronson (Ed.), Improving academic achievement: Impact of psychological factors on education (pp. 37-60). San Diego: Academic Press.

Dweck, C. S., \& Master, A. (2009). Self-theories motivate self-regulated learning. In D. H. Schunk \& B. J. Zimmerman (Eds.), Motivation and self-regulated learning: Theory, research, and applications (pp. 31-51). New York: Routledge.

Eccles, J., \& Wigfield, A. (1985). Teacher expectations and student motivation. In J. B. Dusek (Ed.), Teacher expectancies (pp. 185-228). Hillsdale, NJ: LEA.

Entwisle, D. R., Alexander, K. L., Pallas, A. M., \& Cadigan, D. (1988). A social psychological model of the schooling process over first grade. Social Psychology Quarterly, 51, 173-189.

Garrett, L., Rubie-Davies, C., Alansari, M., Peterson, F., Flint, A., Watson, P., \& McDonald, L. (2015). 'Missing out'? The potential consequences of inaccurate teacher expectations on young gifted readers' achievement outcomes. APEX: The New Zealand Journal of Gifted Education, 19. Retrieved from www.giftedchildren.org.nz/apex. Accessed April 27, 2017.

Gill, S., \& Reynolds, A. J. (1999). Educational expectations and school achievement of urban African American children. Journal of School Psychology, 37, 403-424.

Good, T., \& Brophy, J. (2008). Looking in classrooms. New York: Pearson.

Gravetter, F. J., \& Forzano, L. (2010). Research methods for the behavioral sciences. Belmont, CA: Wadsworth.

Hansford, B. C., \& Hattie, J. A. (1982). The relationship between self and achievement/performance measures. Review of Educational Research, 52, 123-142.

Harris, M. J. (1989). Personality moderators of interpersonal expectancy effects: Replication of Harris and Rosenthal (1986). Journal of Research in Personality, 23, 381-397.

Harris, M. J. (1993). Issues in studying the mediation of expectancy effects: A taxonomy of expectancy situations. In P. D. Blanck (Ed.), Interpersonal expectations: Theory, research, and applications (pp. 350-378). New York: Cambridge University Press.

Harris, M. J., \& Rosenthal, R. (1985). Mediation of interpersonal expectancy effects: 31 meta-analyses. Psychological Bulletin, 97, 363-386.

Harris, M. J., \& Rosenthal, R. (1986). Four factors in the mediation of teacher expectancy effects. In R. S. Feldman (Ed.), The social psychology of education: Current research and theory (pp. 91-114). Cambridge: Cambridge University Press.

Hattie, J. (2008). Visible learning: A synthesis of over 800 meta-analyses relating to achievement. New York: Routledge.

Hayes, A. (2013). Introduction to mediation, moderation, and conditional process analysis. New York, NY: Guilford Press.

Hilton, J. L., \& Darley, J. M. (1991). The Effects of interaction goals on person perception. Advances in Experimental Social Psychology, 24, 235-267. 
Hinnant, J. B., O’Brien, M., \& Ghazarian, S. R. (2009). The longitudinal relations of teacher expectations to achievement in the early school years. Journal of Educational Psychology, 101, 662-670.

Jones, E. E. (1990). Interpersonal perception. New York: Freeman.

Jussim, L. (1986). Self-fulfilling prophecies: A theoretical and integrative review. Psychological Review, 93, 429-445.

Jussim, L. (1989). Teacher expectations: Self-fulfilling prophecies, perceptual biases, and accuracy. Journal of Personality and Social Psychology, 57, 469-480.

Jussim, L. (2012). Social perception and social reality: Why accuracy dominates bias and self-fulfilling prophecy. New York: Oxford University Press.

Jussim, L., \& Eccles, J. (1992). Teacher expectations: II. Construction and reflection of student achievement. Journal of Personality and Social Psychology, 63, 947-961.

Jussim, L., Eccles, J., \& Madon, S. (1996). Social perception, social stereotypes, and teacher expectations: Accuracy and the quest for the powerful self-fulfilling prophecy. Advances in Experimental Social Psychology, 28, 281-388.

Jussim, L., \& Harber, K. D. (2005). Teacher expectations and self-fulfilling prophecies: Knowns and unknowns, resolved and unresolved controversies. Personality and Social Psychology Review, 9, 131-155.

Jussim, L., \& Stevens, S. T. (2016). Why accuracy dominates self-fulfilling prophecies and bias. In S. Trusz \& P. Bąbel (Eds.), Intrapersonal and interpersonal expectancies (pp. 110-116). New York: Routledge.

Krieger, J. L., \& Sarge, M. A. (2013). A serial mediation model of message framing on intentions to receive the human papillomavirus (HPV) vaccine: Revisiting the role of threat and efficacy perceptions. Health Communication, 28, 5-19.

Kuklinski, M. R., \& Weinstein, R. S. (2001). Classroom and developmental differences in a path model of teacher expectancy effects. Child Development, 72, 1554-1578.

Levesque, M. J., \& Lowe, C. A. (1992). The importance of attributions and expectancies in understanding academic behaviour. In F. J. Medway \& T. P. Cafferty (Eds.), School psychology: A social psychological perspective (pp. 47-81). Hillsdale, NJ: Erlbaum.

Li, Z. (2016). The magnitude of teacher expectation effects: Differences in students, teachers and contexts. International Journal of Learning, Teaching and Educational Research, 15, 76-93.

Madon, S., Jussim, L., \& Eccles, J. (1997). In search of the powerful self-fulfilling prophecy. Journal of Personality and Social Psychology, 72, 791-809.

Meece, J. L., Wigfield, A., \& Eccles, J. S. (1990). Predictors of math anxiety and its influence on young adolescents' course enrollment intentions and performance in mathematics. Journal of Educational Psychology, 82, 60-70.

Merton, R. K. (1948). The self-fulfilling prophecy. The Antioch Review, 8, 193-210.

Miller, D. T., \& Turnbull, W. (1986). Expectancies and interpersonal processes. Annual Review of Psychology, 37, 233-256.

Ministry of Science and Higher Education in Poland. (2013). Higher Education System in Poland. Retrieved from http://www.nauka.gov.pl/g2/oryginal/2013_07/ 0695136d37bd577c8ab03acc5c59a1f6.pdf. Accessed April 27, 2017.

Neuberg, S. L. (2016). Motivation matters: The functional context of expectation confirmation processes. In S. Trusz \& P. Bąbel (Eds.), Intrapersonal and interpersonal expectancies (pp. 102-109). New York: Routledge.

Olson, J. M., Roese, N. J., \& Zanna, M. P. (1996). Expectancies. In E. T. Higgins \& A. W. Kruglanski (Eds.), Social psychology: Handbook of basic principles (pp. 211-238). New York: The Guilford Press.

Orne, M. (1962). On the social psychology of the psychological experiment. American Psychologist, 17, $776-783$.

Peterson, E. R., Rubie-Davies, C., Osborne, D., \& Sibley, C. (2016). Teachers' explicit expectations and implicit prejudiced attitudes to educational achievement: Relations with student achievement and the ethnic achievement gap. Learning and Instruction, 42, 123-140.

Rhodewalt, F. (2008). Self-handicapping: On the self-perpetuating nature of defensive behavior. Social and Personality Psychology Compass, 2, 1255-1268.

Rosenthal, R. (1974). On the further evidence for Pygmalion effects and their mediating mechanisms. New York: MSS Modular Publications. 
Rosenthal, R. (1989). The affect/effort theory of the mediation of interpersonal expectation effects. In Donald T. Campbell Award Address, annual convention of the American Psychological Association, New Orleans.

Rosenthal, R. (1997). Interpersonal expectancy effects: A forty-year perspective. Paper presented during The American Psychological Association convention. Chicago, August 16, 1997.

Rosenthal, R., \& Jacobson, L. (1968). Pygmalion in the classroom: Teacher expectation and pupils' intellectual development. New York: Irvington Publisher.

Rosenthal, R., \& Rubin, D. B. (1978). Interpersonal expectancy effects: The first 345 studies. Behavioral and Brain Sciences, 3, 377-386.

Rubie-Davies, C. (2006). Teacher expectations and student self-perceptions: Exploring relationships. Psychology in the Schools, 43, 537-552.

Rubie-Davies, C. (2015). Becoming a high expectation teacher: Raising the bar. New York: Routledge.

Rubie-Davies, C. (2016). High and low expectation teachers: The importance of the teacher factor. In S. Trusz \& P. Bąbel (Eds.), Intrapersonal and interpersonal expectancies (pp. 145-156). New York: Routledge.

Ryan, R. M. (1992). Agency and organization: Intrinsic motivation, autonomy, and the self in psychological development. In J. Jacobs (Ed.), Nebraska symposium on motivation (Vol. 40, pp. 1-56). Lincoln, NE: University of Nebraska Press.

Schunk, D. H., \& Zimmerman, B. J. (Eds.). (2009). Motivation and self-regulated learning: Theory, research, and applications. New York: Routledge.

Sędek, G., \& Kofta, M. (1990). When cognitive exertion does not yield cognitive gain: Toward an informational explanation of learned helplessness. Journal of Personality and Social Psychology, 58, 729-743.

Smith, E., Jussim, L., \& Eccles, J. (1999). Do self-fulfilling prophecies accumulate, dissipate, or remain stable over time? Journal of Personality and Social Psychology, 77, 548-565.

Snow, R. E. (1995). Pygmalion and intelligence? Current Directions in Psychological Science, 4, $169-171$.

Snyder, M., \& Klein, O. (2005). Construing and constructing others: On the reality and the generality of the behavioral confirmation scenario. Interaction Studies, 6, 53-67.

Snyder, M., \& Stukas, A. A. (1999). Interpersonal processes: The interplay of cognitive, motivational, and behavioral activities in social interaction. Annual Review of Psychology, 50, 273-303.

Speybroeck, S., Kuppens, S., van Damme, J., van Petegem, P., Lamote, C., Boonen, T., et al. (2012). The role of teachers' expectations in the association between children's SES and performance in kindergarten: A moderated mediation analysis. PLOS ONE. https://doi.org/10.1371/journal.pone. 0034502 .

Spitz, H. H. (1999). Beleaguered Pygmalion: History of the controversy over claims that teacher expectancy raises intelligence. Intelligence, 27, 199-234.

Stevenson, H. W., \& Newman, R. S. (1986). Long-term prediction of achievement and attitudes in mathematics and reading. Child Development, 57, 646-659.

Swann, W. B., \& Ely, R. J. (1984). A battle of wills: Self-verification versus behavioral confirmation. Journal of Personality and Social Psychology, 46, 1287-1302.

Trusz, S., \& Bąbel, P. (Eds.). (2016). Intrapersonal and interpersonal expectancies. New York: Routledge.

Trzesniewski, K. H., Kinal, M., \& Donnellan, M. B. (2010). Self-enhancement and self-protection in developmental context. In M. Alicke \& C. Sedikides (Eds.), The handbook of self-enhancement and self-protection (pp. 341-357). New York: Guilford.

Turek, K. (2011). The unemployed: The untapped resources of Polish economy. Warsaw: Polish Agency for Enterprise Development.

Urhahne, D., \& Zhu, M. (2016). Teacher judgment and student motivation. In C. M. Rubie-Davies, J. M. Stephens, \& P. Watson (Eds.), The Routledge international handbook of social psychology of the classroom (pp. 304-315). London: Routledge.

Valentine, J. C., Dubois, D. L., \& Cooper, H. (2004). The relation between self-beliefs and academic achievement: A meta-analytic review. Educational Psychologist, 39, 111-133.

van den Bergh, L., Denessen, E., Hornstra, L., Voeten, M., \& Holland, R. W. (2010). The implicit prejudiced attitudes of teachers: Relations to teacher expectations and the ethnic achievement gap. American Educational Research Journal, 47, 497-527. 
van Gogh, T., Ericsson, K. A., Rikers, R. M. J. P., \& Paas, F. (2005). Instructional design for advanced learners: Establishing connections between the theoretical frameworks of cognitive load and deliberate practice. Educational Technology Research and Development, 53, 73-81.

Weathington, B. L., Cunningham, C. J., \& Pittenger, D. J. (2010). Research methods for the behavioral and social sciences. Hoboken, NJ: Wiley.

Weinstein, R. S. (2002). Reaching higher: The power of expectations in schooling. Cambridge, MA: Harvard University Press.

Weinstein, R. S., Marshall, H. H., Brattesani, K., \& Middlestadt, S. E. (1982). Student perceptions of differential teacher treatment in open and traditional classrooms. Journal of Educational Psychology, 74, 678-692.

Weinstein, R. S., \& Middlestadt, S. E. (1979). Student perceptions of teacher interactions with male high and low achievers. Journal of Educational Psychology, 71, 421-431.

Wigfield, A., \& Eccles, J. (2000). Expectancy-value theory of achievement motivation. Contemporary Educational Psychology, 25, 68-81.

Willard, J., \& Madon, S. (2016). Understanding the connections between self-fulfilling prophecies and social problems. In S. Trusz \& P. Bąbel (Eds.), Intrapersonal and interpersonal expectancies (pp. 117-125). New York: Routledge.

Wineburg, S. S. (1987). The self-fulfillment of the self-fulfilling prophecy: A critical appraisal. Educational Researcher, 16, 28-37.

World Bank Data. (2017). Retrieved from http://data.worldbank.org/indicator/SE.TER.ENRR?locations= PL. Accessed April 27, 2017.

Sławomir Trusz Ph.D., is an Assistant Professor of Pedagogy and Head of Educational Microprocesses Laboratory at the Pedagogical University in Krakoęw, Poland. His leading area of interest are intra- and interpersonal expectancies effects and educational self-fulfilling prophecy phenomenon. His recent studies were focused on stereotyping, prejudice and discrimination in relation to circular migrants' children in Europe. He co-authored the book entitled "Intrapersonal and interpersonal expectancies", Routledge, 2016 (with Przemysław Bąbel (Jagiellonian University in Poland). 